\title{
FOR THE RECORD
}

\section{Crystallization and preliminary X-ray diffraction studies on recombinant isopenicillin $\mathrm{N}$ synthase from Aspergillus nidulans}

\author{
PETER L. ROACH, ${ }^{1}$ CHRISTOPHER J. SCHOFIELD,${ }^{1}$ JACK E. BALDWIN, ${ }^{1}$ \\ IAN J. CLIFTON, ${ }^{2}$ AND JANOS HAJDU ${ }^{2}$ \\ ' Dyson Perrins Laboratory and Oxford Centre for Molecular Sciences, \\ University of Oxford, South Parks Road, Oxford OX1 3QY, United Kingdom \\ 2 Laboratory of Molecular Biophysics and Oxford Centre for Molecular Sciences, University of Oxford, \\ The Rex Richards Building, South Parks Road, Oxford OX1 3QU, United Kingdom
}

(ReCEIVED January 19, 1995; ACCEPTED March 15, 1995)

\begin{abstract}
Recombinant Aspergillus nidulans isopenicillin N synthase was purified from an Escherichia coli expression system. The apoenzyme in the presence of saturating concentrations of $\mathrm{MnCl}_{2}$ could be crystallized by either macro- or microseeding, using the hanging drop vapor diffusion technique with polyethylene glycol 8000 as precipitant. The crystals $(0.5-1.0 \mathrm{~mm}$ overall dimensions) diffract X-rays to at least $2.0 \AA$ resolution at synchrotrons and belong to space group $\mathrm{P} 22_{1} 2_{1} 2_{1}$ with unit cell dimensions of $a=59.2 \AA, b=127.0 \AA$, and $c=139.6 \AA$. The asymmetric unit contains one dimer, and the solvent content of the crystals is $60 \%$. The crystals are radiation sensitive.
\end{abstract}

Keywords: $\beta$-lactam antibiotics; crystallization; isopenicillin $\mathrm{N}$ synthase; oxygenase; penicillin biosynthesis; $\mathrm{X}$-ray diffraction

Despite the fact that $\beta$-lactams have held an almost unique fascination for synthetic organic chemists for more than 50 years, there is still no efficient synthesis of the penicillins, which were the first $\beta$-lactams to be discovered. In contrast, isopenicillin $N$ synthase (IPNS) utilizes iron and molecular oxygen to remove four hydrogen atoms from a linear tripeptide $(\mathrm{L}-\delta$ - $(\alpha$-aminoadipoyl)-L-cysteinyl-D-valine, ACV) and thereby synthesizes the labile and strained ring structure of penicillin in a single event (for reviews, see Baldwin \& Bradley, 1990; Baldwin \& Schofield, 1993; Feig \& Lippard, 1994). There is no synthetic precedent for this unique process (Fig. 1).

The product, isopenicillin $\mathrm{N}$, is the first formed bicyclic $\beta$-lactam in the penicillin and cephalosporin biosynthetic pathway and is the precursor of all other penicillins and cephalospor-

Reprint requests to: Janos Hajdu, Laboratory of Molecular Biophysics, University of Oxford, The Rex Richards Building, South Parks Road, Oxford OX13QU, UK; e-mail: janos@biop.ox.ac.uk. ins. An understanding of catalysis by IPNS may lead to the invention of new chemical reactions with widespread applications in science, industry, and medicine.

We have recently reported the crystallization of a recombinant isopenicillin $\mathrm{N}$ synthase from Cephalosporium acremonium (Fujishima et al., 1994). These crystals diffracted X-rays to about $3.5 \AA$ resolution only. The sudden fall-off of the intensity of reflections in the diffraction pattern was indicative of a "disorder of the second kind" (Vainshtein, 1966; Martin Fernandez et al., 1994), suggesting that the molecule was flexible in the lattice of these crystals.

This paper describes a new and greatly improved crystal form of IPNS obtained from a different organism, using a recombinant Aspergillus nidulans enzyme purified from an Escherichia coli expression system (Baldwin et al., 1990, 1991). The new crystals are large $(0.5-1.0 \mathrm{~mm}$ overall) and show well-ordered diffraction to about $2.0 \AA$ resolution at synchrotrons.

Protein purification. Recombinant E. coli cells expressing $A$. nidulans IPNS were grown according to Baldwin et al. (1991) and the harvested cells were stored at $-80^{\circ} \mathrm{C}$. All purification procedures were carried out at $4{ }^{\circ} \mathrm{C}$ and all resins and columns were obtained from Pharmacia (Uppsala, Sweden). The frozen cells $(100 \mathrm{~g})$ were resuspended in lysis buffer $(300 \mathrm{~mL}, 50 \mathrm{mM}$ Tris- $\mathrm{HCl}, \mathrm{pH} 8.0,5 \mathrm{mM}$ EDTA, $0.1 \%$ Triton, $0.1 \% \beta$-mercaptoethanol) and lysed using a flow-through sonicator (model W-380, Life Science Laboratories Ltd., Luton, UK). Polyethyleneamine 50,000 solution $(5 \% \mathrm{w} / \mathrm{v}, \mathrm{pH} 8.0$, with $\mathrm{HCl})$ was added to a final concentration of $0.15 \% \mathrm{w} / \mathrm{v}$ and the lysate was then centrifuged at $26,000 \times g$ for $30 \mathrm{~min}$. The supernatant was then applied to a $300-\mathrm{mL}$ Q-Sepharose FF ion-exchange column equilibrated with column buffer $\mathrm{A}(50 \mathrm{mM}$ Tris- $\mathrm{HCl}, \mathrm{pH} 8.0$, $5 \mathrm{mM}$ EDTA). The column was then washed with $700 \mathrm{~mL}$ of column buffer $\mathrm{A}$ and the protein was eluted with a linear gra- 
<smiles>CC(C)[C@H](NC(=O)[C@H](CS)NC(=O)CCC[C@H]([NH3+])C(=O)[O-])C(=O)[O-]</smiles>

$L$ - $\delta$-( $\alpha$-aminoadipoyl)- $L$-cysteinyl- $D$-valine

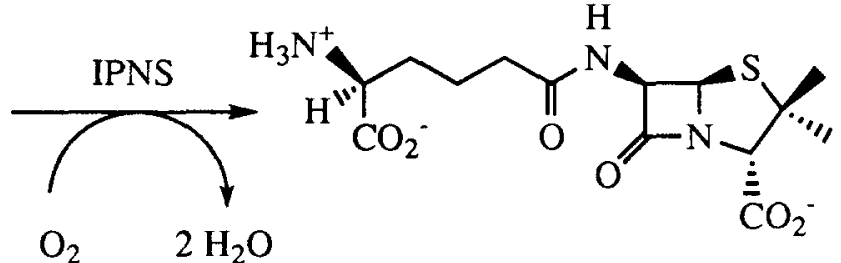

Isopenicillin $\mathrm{N}$

Fig. 1. Synthesis of isopenicillin $\mathrm{N}$ from $\mathrm{ACV}$ by isopenicillin $\mathrm{N}$ synthase.

dient from 0 to $60 \%$ of column buffer B $(50 \mathrm{mM}$ Tris- $\mathrm{HCl}$, pH 8.0, $5 \mathrm{mM}$ EDTA, $500 \mathrm{mM} \mathrm{NaCl}$ ) over $2,000 \mathrm{~mL}$. The purest fractions, as judged by SDS-PAGE, were combined and concentrated to approximately $50 \mathrm{mg} / \mathrm{mL}$ using an Amicon ultrafiltration concentrator equipped with a PM30 membrane. This protein was applied, in four batches, to a Superdex 75 (preparative grade) gel filtration column $(33 \times 850 \mathrm{~mm})$ equilibrated in column buffer $A$ at a flow rate of $3 \mathrm{~mL} / \mathrm{min}$. The IPNS fractions eluted between 350 and $400 \mathrm{~mL}$, and the purest fractions, as judged by SDS-PAGE, were combined and applied in batches of between 70 and $100 \mathrm{mg}$ to a Mono-Q 16/10 ion-exchange column equilibrated with column buffer $\mathrm{C}(50 \mathrm{mM}$ Tris- $\mathrm{HCl}$, $\mathrm{pH}$ 8.0). The column was then washed with $80 \mathrm{~mL}$ of column buffer $\mathrm{C}$, and the protein was eluted with a linear gradient from 0 to $50 \%$ of column buffer D $(50 \mathrm{mM}$ Tris- $\mathrm{HCl}, \mathrm{pH} 8.0,500 \mathrm{mM}$ $\mathrm{NaCl}$ ) over $250 \mathrm{~mL}$. Fractions were analyzed for purity by SDS-PAGE and the purest fractions pooled and concentrated. The protein was exchanged into $25 \mathrm{mM}$ Tris- $\mathrm{HCl}, \mathrm{pH} 8.0$, using a PD10 column and then concentrated to between 40 and $50 \mathrm{mg} / \mathrm{mL}$. Aliquots $(50 \mu \mathrm{L})$ of protein were stored at $-80^{\circ} \mathrm{C}$. Enzyme activity measurements were performed using a bioassay method (Pang et al., 1984).

Crystallization. Initial crystallization trials using the apoenzyme and in the presence of $\mathrm{Fe}(\mathrm{II}), \mathrm{Cu}(\mathrm{II}), \mathrm{Mn}$ (II), $\mathrm{Co}$ (II), and $\mathrm{Zn}$ (II) salts were performed using versions of the random screening method of Jancarik and Kim (1991). Type 1 crystals (thin needles) were obtained by the hanging drop vapor diffusion technique, using $20 \%$ polyethylene glycol (PEG) 8000 buffered with $100 \mathrm{mM}$ Tris- $\mathrm{HCl}, \mathrm{pH} 8.5$, as precipitant. The size of these crystals could be improved by the addition of sodium citrate $(200 \mathrm{mM})$ to the precipitant, but the resulting crystals $(0.1 \times 0.1 \times 0.3 \mathrm{~mm})$ gave poor diffraction.

An improved crystal form (type 2) was obtained using $24 \%$ PEG $8000,100 \mathrm{mM}$ Tris- $\mathrm{HCl}, \mathrm{pH} 8.5$, and $5 \mathrm{mM} \mathrm{MnCl}_{2}$. The conditions were optimized by varying the protein, precipitant, salt, and buffer concentrations. Both macro- and microseeding techniques were successful. Large crystals (rectangular columns with dimensions of $1 \times 0.20 \times 0.15 \mathrm{~mm}$ ) were obtained by microseeding using $24 \% \mathrm{PEG} 8000,5 \mathrm{mM} \mathrm{MnCl}_{2}$, and $100 \mathrm{mM}$ Tris$\mathrm{HCl}, \mathrm{pH} 8.5$, as the precipitant, and mixing the precipitant and protein solution in a $1: 1$ ratio at $18^{\circ} \mathrm{C}$. The drops were suspended over wells containing $100 \mathrm{mM}$ Tris- $\mathrm{HCl}, \mathrm{pH} 8.5$, and $16 \%$ PEG 8000 . These crystals grew to maximum size after 10-14 days and had to be harvested and stored in a solution containing $20 \%$ PEG $8000,100 \mathrm{mM}$ Tris- $\mathrm{HCl}, \mathrm{pH} 8.5$, and $5 \mathrm{mM} \mathrm{MnCl}_{2}$. If left in the droplet, the crystals started to dissolve after 3-4 weeks.
$X$-ray analysis. Data on these crystals were collected at $4^{\circ} \mathrm{C}$ at the European Synchrotron Radiation Facility (ESRF; Grenoble, France) and the Photon Factory (Tsukuba, Japan) and at $18^{\circ} \mathrm{C}$ on a Rigaku rotating anode X-ray source equipped with an MAR Research imaging plate detector in Oxford. At the ESRF, the initial diffraction pattern extended to $2.0 \AA$ resolution with some reflections beyond that limit. The diffraction limit dropped to about $2.5 \AA$ after the first $5^{\circ}$ of data collection, indicating that the crystals were radiation sensitive. Data were analyzed using DENZO (Otwinowski, 1993), and are consistent with space group $\mathrm{P} 2{ }_{1} 2_{1} 2_{1}$ with unit cell dimensions of $a=59.2 \AA$, $b=127.0 \AA, c=139.6 \AA$, and one dimer in the asymmetric unit $\left(R_{\text {sym }}=0.061\right.$ for data in the resolution range of 2.6-2.5 $\AA$ in the best ESRF data set, overall completeness of combined data to $2.5 \AA=98.1 \%$ ). The crystal parameters give $V_{m}=3.55$ $\AA^{3} / \mathrm{Da}$ and a solvent content of $60 \%$, i.e., above the average, but within the range observed for protein crystals (Matthews, 1968, 1977).

\section{Acknowledgments}

We thank Dr. Y. Fujishima for helpful discussions and Dr. I. Andersson for help with synchrotron data collection. We thank Mrs. W. Sobey, Mr. M. Sami, Mr. J. Pitt, and Mr. J. Keeping for expert technical help. We also thank the staff and scientists operating the synchrotron beam lines used in these studies: Drs. B. Rasmussen and A. Åberg at the ESRF, and Prof. N. Sakabe and Drs. N. Watanabe and S. Ikemizu at the Photon Factory, Work was supported by the M.R.C., the Oxford Centre for Molecular Sciences, and the B.B.S.R.C., together with Zeneca Pharmaceuticals via a D.T.I. Link Scheme.

\section{References}

Baldwin JE, Blackburn JM, Schofield CJ, Sutherland JD. 1990. High level expression in Escherichia coli of a fungal gene under the control of strong promotor. FEMS Microbiol Lett 68:45-52.

Baldwin JE, Blackburn JM, Sutherland JD, Wright MC. 1991. High-level soluble expression of isopenicillin N synthase isozymes in E. coli. Tetrahedron 47:5991-6002.

Baldwin JE, Bradley M. 1990. Isopenicillin N synthase: Mechanistic st udies. Chem Rev 90:1079-1088.

Baldwin JE, Schofield CJ. 1993. The biosynthesis of $\beta$-lactams. In: Page MI, ed. The chemistry of $\beta$-lactams. London: Blackie. pp 1-78.

Feig AL, Lippard SJ. 1994. Reactions of nonheme iron(II) centers with dioxygen in biology and chemistry. Chem Rev 94:759-805.

Fujishima Y, Nordlund P, Pelosi G, Schofield CJ, Cole SCJ, Baldwin JE, Hajdu J. 1994. Crystallisation and preliminary X-ray diffraction studies on a recombinant isopenicillin $\mathrm{N}$ synthase from Cephalosporium acremonium. J Mol Biol 242:712-714.

Jancarik J, Kim SH. 1991. Sparse matrix sampling: A screening method for crystallization of proteins. $J$ Appl Crystallogr 24:409-411. 
Martin Fernandez ML, Bordas J, Diakun G, Harris J, Lowy J, Mant GR, Svensson A, Towns-Andrews E. 1994. Time-resolved X-ray diffraction studies in live frog sartorius muscle during isometric and isotonic contractions. J Muscle Res Cell Motil 15:319-348.

Matthews BW. 1968. Solvent content of protein crystals. $J$ Mol Biol 33:491-497.

Matthews BW. 1977. X-ray structure of proteins. In: Neurath H, Hill RL, eds. The proteins, vol 3. New York: Academic Press. pp 403-590.
Otwinowski Z. 1993. Oscillation data reduction program. In: Sawyer L, Isaacs NW, Bailey S, eds. Data collection and processing. Warrington, UK: Daresbury Laboratory. pp 71-79.

Pang CP, Chakravarti B, Adlington RM, Ting HH, White RL, Jayatilake GS, Baldwin JE, Abraham EP. 1984. Purification of isopenicillin N synthase. Biochem J 222:789-795.

Vainshtein BK. 1966. Diffraction of $X$-rays by chain molecules. Amster$\mathrm{dam} /$ London/New York: Elsevier.

\section{Forthcoming Papers}

Domains in folding of model proteins

V.I. Abkevich, A.M. Gutin, and E.I. Shakhnovich

Probing the solution structure of the DNA-binding protein Max by a combination of proteolysis and mass spectrometry

S.L. Cohen, A.R. Ferré-D'Amaré, S.K. Burley, and B.T. Chait

Interactions between hydrophobic side chains within $\alpha$-helices

T.P. Creamer and G.D. Rose

Interaction of SecB with intermediates along the folding pathway of maltose-binding protein

D.L. Diamond, S. Strobel, S.-Y. Chun, and L.L. Randall

A phage display system for studying the sequence determinants of protein folding

H. Gu, Q. Yi, S.T. Bray, D.S. Riddle, A.K. Shiau, and D. Baker

Covalent control of 6-phosphofructo-2-kinase/fructose-2,6-bisphosphatase: Insights into autoregulation of a bifunctional enzyme

\section{I.J. Kurland and S.J. Pilkis}

Quantitative approaches to utilizing mutational analysis and disulfide cross-linking for modeling a transmembrane domain

G.F. Lee and G.L. Hazelbauer

Quantitative measurements of the cooperativity in an EF-hand protein with sequential calcium binding

\section{S. Linse and W.J. Chazin}

Crystallization and preliminary X-ray investigation of lipoxygenase-3 from soybeans

J. Steczko, W. Minor, V. Stojanoff, and B. Axelrod

Three-dimensional structure of the complex of 4-guanidino-Neu5Ac2en and influenza virus neuraminidase

J.N. Varghese, V.C. Epa, and P.M. Colman 